\title{
THE CONNECTIONS OF THE BASAL OPTIC ROOT (POSTERIOR ACCESSORY OPTIC TRACT) AND ITS NUCLEUS IN VARIOUS MAMMALS
}

\author{
LOIS A. GILLILAN \\ Department of Anatomy, University of Michigan, Ann Arbor ${ }^{1}$
}

FIVE FIGURES

CONTENTS

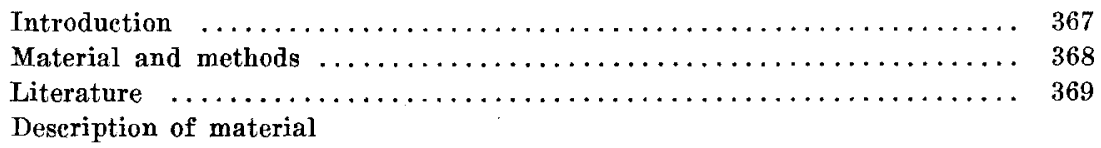

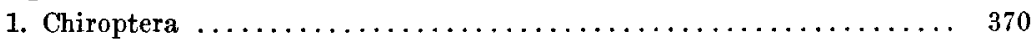

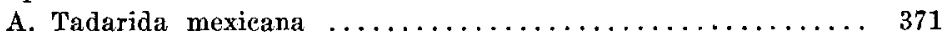

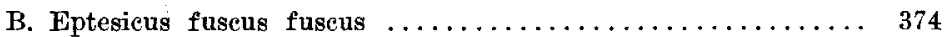

C. Xantharpyia amplexicaudata $\ldots \ldots \ldots \ldots \ldots \ldots \ldots \ldots \ldots \ldots \ldots$

2. Insectivora. Blarina brevicauda $\ldots \ldots \ldots \ldots \ldots \ldots \ldots \ldots \ldots \ldots \ldots$

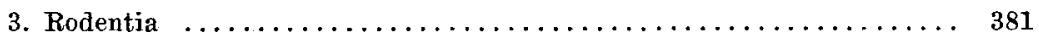

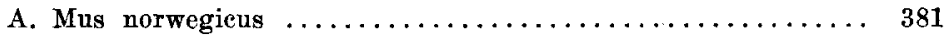

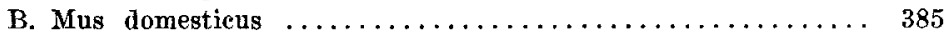

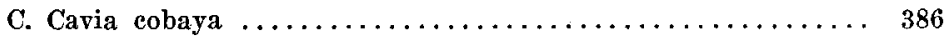

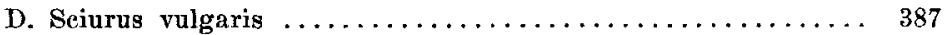

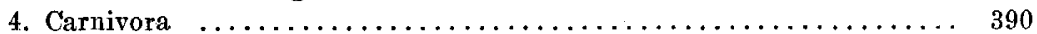

5. Ungulata. Elephas indicus $\ldots \ldots \ldots \ldots \ldots \ldots \ldots \ldots \ldots \ldots \ldots \ldots \ldots$

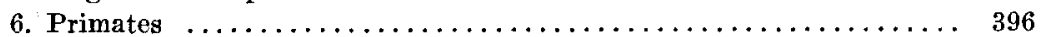

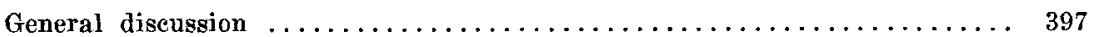

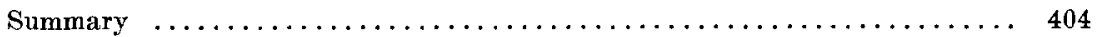

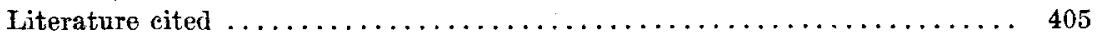

\section{INTRODUCTION}

The material presented in this paper is the result of studies on the accessory optic tracts in various mammals including representatives of the orders from rodents through primates.

- A dissertation submitted in partial fulfilment of the requirements for the degree of doctor of philosophy in the University of Michigan. 
Particular attention has been paid to the degree of development of these accessory tracts as compared with the size of the eyes and optic tract, and some attempt has been made to correlate these findings with the habits of the animal and the possible function of this accessory system.

\section{MATERIAL AND METHODS}

In the normal studies, serial sections of brains of the free-tailed bat (Tadarida mexicana), the common American shrew (Blarina brevicauda), the albino rat (Mus norwegicus), the mouse (Mus domesticus), the guinea pig (Cavia cobaya), the cat (Felis domestica), and the monkey (Macaca mulatta) were provided from the neurological collection of the Laboratory of Comparative Neurology of the Department of Anatomy at the University of Michigan. Serial sections of the normal brain of the big brown bat, Eptesicus fuscus fuscus, were prepared during the course of the study.

The material of Tadarida mexicana and Eptesicus fuscus fuscus included seven complete series stained by the toluidin blue method to show nuclear groups, by pyridine silver to indicate both fiber tracts and nuclear groups, and by the Pal-Weigert or Weil methods to show fiber tracts. The sections represented three planes: transverse, sagittal and horizontal. Three complete series of Blarina brevicauda, stained by toluidin blue and pyridine silver, were used.

For the normal rodent material, five complete series were studied, similar in stains and planes to those of the bat. Pyridine silver seetions of normal mouse and Pal-Weigert sections of guinea pig were employed as check references in the rodent group.

In the carnivore study normal brains cut in transverse and horizontal section and stained by pyridine silver, Weil, and toluidin blue were used. For the primate group only transverse sections of Weil and toluidin blue were available.

The sections of Xantharpyia amplexicaudata (fruit bat), Sciurus vulgaris (squirrel), and Elephas indicus (elephant) were examined at the Central Institute for Brain Research, Amsterdam. These sections were all cut transversely and stained by the Pal-Weigert method, and the two former were counterstained by paracarmine.

The experimental material was prepared as follows: An eye was removed from the anesthetized animal under aseptic conditions. The socket was then packed with cotton dipped in iodoform and sealed in place with celloidin. In the larger animals it was necessary to sew the eyelids together with sterile gut. Degeneration time for the Marehi material was 10 to 15 days and for the Weil material 6 weeks 
or longer. Immediately after the animals were killed, the brains were removed and then placed in the fixing fluid as soon as possible. In the case of one rat brain every third section was stained by the Weil method; for the other two the Bodian silver method and toluidin blue technique were employed respectively. One bat brain had alternate sections prepared to show the Marchi granules of degenerated tracts and the other sections stained by iron-hematoxylin and eosin.

The figures herein contained were drawn by means of a projection apparatus. Certain details, however, were added by the use of the microscope.

The author would like to take this opportunity to thank Dr. Elizabeth C. Crosby for her interest in the direction of this problem and her untiring assistance and helpful and inspiring criticism during the course of the work. It is also through her kindness that the neurological collection of the Laboratory of Comparative Neurology of the Department of Anatomy at the University of Michigan has been made available for study.

I wish to thank Prof. C. U. Ariëns Kappers for the courtesy of the laboratory at the Central Institute of Brain Research, Amsterdam, and for the material placed at my disposal. I am grateful also for the assistance which Dr. J. L. Addens rendered me during my stay at the Institute.

To Prof. R. D. Lockhart I express my thanks for the use of the laboratory and for the facilities available in the Department of Anatomy at Marischal College, University of Aberdeen, which made possible the completion of this work. Part of the detailed cell structure of the nuclei was done with a special microscope provided Dr. Crosby by the Carnegie Trust for the Universities of Scotland.

The carrying out of this work was made possible by the Mary E. Woolley Fellowship from Mount Holyoke College for the year 193839 and by a University Fellowship and the Carl W. Braun Fellowship from the University of Michigan for 1939-40.

\section{LITERATURE}

Von Gudden (1881) claimed that in 1870 he gave the first published recognition to tractus opticus basalis as it is recognized today. He proved and confirmed the connection of this tract with the eye. Marburg ('03 a) observed the fact that the nucleus of tractus peduncularis transversus of higher mammals was in the same position at the base of the brain as nucleus ectomamillaris of lower vertebrates and had the same histological characteristics; he thus came to the 
conclusion that the basal optic root of birds and reptiles with its termination in nucleus ectomamillaris was equivalent to the mammalian tractus peduncularis transversus and its terminal nucleus. Bochenek ('08) described tractus opticus basalis and called it tractus opticus accessorius posterior, as it terminates caudal to another tract originating in the retina which ends somewhat more rostrally in nucleus subthalamicus. However, the other descriptions of the mammalian posterior accessory optic tract as given by a number of observers, including von Monakow (1889), Pavlow ('00), Wallenberg ('04), Loepp ('12), Münzer and Wiener ('12), Kosaka and Hiraiwa ('15), Brouwer ('23), Castaldi ('23), Tsai ('25), Gurdjian ('27), and most recently Frey ('35, '37), indicate that it is the tract in question, namely tractus opticus basalis. For purposes of simplifying and standardizing the nomenclature the terms tractus opticus basalis and nucleus tractus optici basalis will be used in this paper to designate this tract of retinal origin which runs below the cerebral peduncle to end in a nucleus at the base of the brain.

The name tractus opticus accessorius anterior as applied by Bochenek ('08) to the optic fiber bundle terminating more anteriorly in nucleus subthalamicus will be retained here. This tract has also been recognized by Loepp ('12), Kosaka and Hiraiwa ('15), and Tsai ('25). Ariëns Kappers, Huber and Crosby ('36) give an exhaustive resume of the literature on this subject, and other references to the pertinent literature will be made throughout the report. A preliminary survey of the results contained in this paper are given by Gillilan ('39).

In forms below mammals the basal optic root has been described fully and carefully. For references to the literature the reader is referred to the Ariëns Kappers, Huber and Crosby ('36) text.

\section{Chiroptera}

Descriptions of the gross anatomy of the brain and optic tracts of chiropteres and insectivores are available through the accounts of Le Gros Clark ('28, '33) on Insectivora, Ganser (1882) on the mole, and Ärnbäck-Christie-Linde ('00) on Vesperugo pipistrellus (bat). Some of these papers include limited accounts of a few specific regions of these brains, but none of them mentions the accessory optic tracts, so that as far as the literature is concerned we must depend upon the descriptions of these tracts in other animals. 
Suzuki ('36) has described nucleus tractus optici basalis in Xantharpyia amplexicaudata, a normal-eyed fruit bat, together with some of its connections. His data are based on a single, normal cross-section series, stained by Pal-Weigert and paracarmine, which was also used in this study. This observer's paper is discussed more fully below.

A. Tadarida mexicana. Humphrey ('36) found in her study of the telencephalon of the bat that the brain showed evidences of compression in the reduction in size of the ventricles, the shallow fissures, and the compact nuclear masses. The brain is crowded dorsally so that it forms a right angle in the middorsal region. This was confirmed in the present investigation for it was found that, especially in the region of the mammillary bodies and nucleus interpeduncularis, the more cephalic structures were telescoped backward into the more dorsal structures.

The optic tract in Tadarida mexicana is rather small, and a considerable bundle of fibers continues around the lateral geniculate body to the region of the superior colliculus. The eye of this bat is small but is larger than the optic apparatus of moles and shrews, since the bat inhabits the world at large and is not a burrowing animal.

Tractus opticus basalis is large and unusually distinct in the pyridine silver preparations. The bundle of fibers that makes up this tract accompanies the optic tract, occupying a caudal and ventral position to levels behind the chiasma, where it crosses in the posterior portion. It is first seen most clearly in the transverse sections to turn off from the optic tract at the anteroventral pole of the medial geniculate nucleus and to course along the base of the cerebral peduncle (fig. 1A). A large bundle of fibers sweeps around the medial end of the peduncle to terminate in nucleus tractus optici basalis (fig. 1C), which is equivalent to nucleus ectomamillaris of Gurdjian ('27) and nucleus opticus tegmenti of Tsai ('25). This nucleus lies caudal and medial to nucleus subthalamicus, occupying a position between the medial end of the cerebral peduncle laterally and the posterior tip of the mammillary body and 
the anterior pole of nucleus interpeduncularis medially. The fact that nucleus tractus optici basalis comes into relationship with nucleus interpeduncularis suggests the telescoping of the structures in this region. The emerging fibers of the oculomotor nerve cut through nucleus tractus optici basalis in the small-eyed bat, although in most forms the nucleus is well in front of the nerve.

The fibers of the anterior accessory optic tract may be traced to nucleus subthalamicus. It is evident in both transverse and sagittal sections that as tractus opticus basalis passes below the cerebral peduncle the anterior accessory optic tract separates from it and passes dorsally among the fiber bundles of the peduncle toward nucleus subthalamicus. How-

\section{ABBREVIATIONS}

aa, tractus pedunculo-opticus accessorius

b, decussatio supramamillaris

eh.op., chiasma opticum

c.mam., corpus mamillare

F., Fornix

med.l., lemniseus medialis

n.III, nucleus nervii oculomotorii

n.g.l., nucleus geniculatus lateralis

n.g.m., uucleus geniculatus medialis

n.interped., nueleus interpeduncularis

N.op., nervus opticus

n.pretect., nucleus pretectalis

n.ruber, nucleus ruber

n.subthal., nucleus subthalamicus

n.tr.op.ace.post., nucleus tractus optici accessorii posterioris

n.tr.op.b., nucleus tractus optiei basalis

op.tect., tectum opticum

ped.cer., pedunculus cerebri

ped.mam., peduneulus mamillaris

r.III, root of oculomotor nerve

s.nigra, substantia nigra

tr.hab.ped., tractus habenulo-peduneuIaris

tr.mam.thal. + teg., tractus mamillothalamieus et tegmentalis

tr.op., tractus opticus

tr.op.acc.ant., tractus opticus accessorius anterior tr.op.ace.post., tractus opticus accessorius posterior

tr.op.b., tractus opticus basalis

tr.op.-interped., tractus optico-interpeduncularis

tr.op.-nig.ace, tractus optico-nigralis accessorius

tr.op.oc., tractus optico-oculomotorius

tr.op.-oc.ace, tractus optico-oculomotorius accessorius

tr.op.-ret.ace, tractus optico-reticularis accessorius

1, tractus opticus basalis

2 , tractus optico-nigralis

3 , tractus optico-reticularis

4, tractus optico-oculomotorins

5 , tractus optico-commissuralis

6 , tractus optico-interpeduncularis

a, tractus optico-nigralis accessorius

b, tractus optico-reticularis accessorius

c, tractus optico-oculomotorius accessorius

d, tractus optico-commissuralis accessorius

e, tractus subthalamo-nigralis

f, tractus tegmento-spinalis

$g$, tractus nigro-tectalis

$h$, connection with the mammillary peduncle 


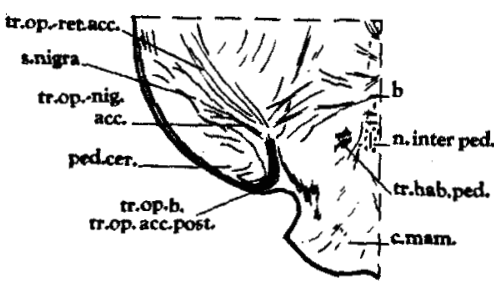

A

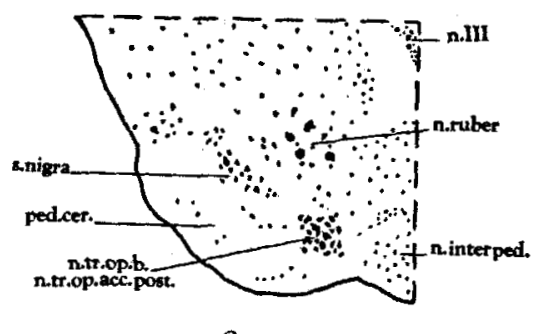

c

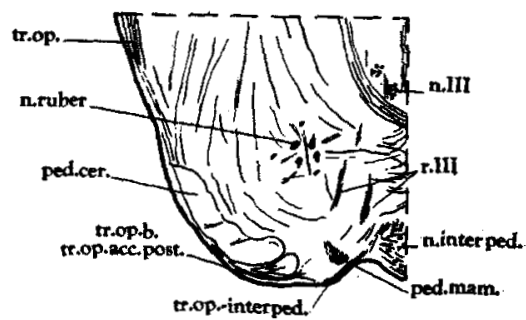

B

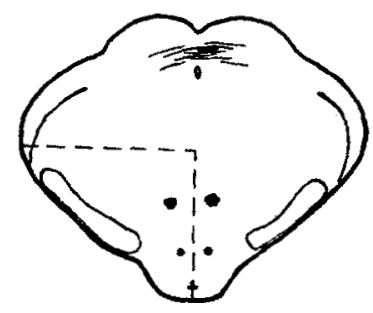

D

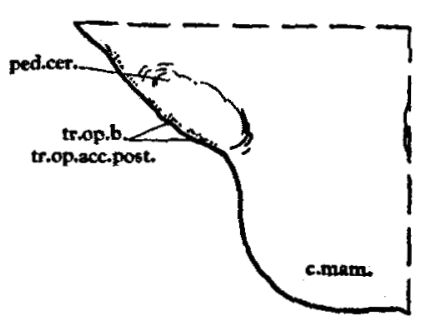

$\mathbf{p}$

Fig. 1 Transverse sections through the diencephalon and midbrain of Tadarida mexicana ( $A, B$, and $C$ ) and Eptesicus fuscus fuscus ( $E$ and $F$ ), $\times 20$. A. A pyridine silver section showing tractus opticus basalis in its course below the cerebral peduncle and its terminal portion just before its entrance into nucleus tractus optici basalis. Other secondary connections of the nucleus are shown. B. A pyridine silver section illustrating the most caudal part of tractus optieus basalis and its connection with nucleus interpeduncularis. C. A toluidin blue section showing the position of nucleus tractus optici basalis. D. A diagram of a transverse section for orientation of figures 1 to 4 . $\mathrm{E}$ and $\mathrm{F}$. Marchi degeneration sections showing the positions of tractus optieus accessorius anterior and tractus opticus basalis, respectively. 
ever, its connection with this nucleus is not so clear in the normal material of the bat brain as in that of some other forms. A very distinct, small group of fibers from the caudal end of tractus opticus basalis enters the fibrous capsule of nucleus interpeduncularis (fig. 1B).

B. Eptesicus fuscus fuscus. ${ }^{2}$ The brain of the big brown bat is larger than that of the free-tailed bat, but the optic system is in the same proportion of smallness. The eyes are tiny in this form and the optic nerves appear as slender threads on the ventral surface of the intact brain. The normal anatomy conforms to that of Tadarida mexicana, but one very interesting fact was brought forth in the Weil sections. The optic tract is very heavily medullated, and there is no difficulty in following its course throughout the series. Tractus opticus basalis, however, is very thinly medullated and is seen as a very slender strand of fibers running below the peduncle. This strand turns around the end of the peduncle, but the course of the terminal fibers is indistinet as they very soon lose all their myelin.

After operation the big brown bats were kept alive and in good condition until they were killed at intervals of 7 to 13 days for the Marchi degeneration series. One animal, kept alive 28 days, died unexpectedly; the brain was removed immediately upon discovery of death and was fixed and stained by the Weil technique.

This latter series showed no degeneration in the optic tract, but there was a slight degeneration in tractus opticus basalis on the opposite side from the enucleation. The Marchi series indicate that tractus opticus basalis is primarily crossed with some uncrossed fibers. The degeneration of this tract after enucleation of an eye gives indisputable evidence that tractus opticus basalis has its origin in the retina and is a single neuron pathway from the retina to nuclear centers of the midbrain (fig. 1F).

The Marchi series also provide positive evidence for the existence of the anterior accessory optic tract (fig. 1E), the

\footnotetext{
? These bats were identified by Dr. W. H. Burt of the University Museum, University of Michigan.
} 
presence of which is not always discernible in normal preparations. The fibers leave tractus opticus basalis and run through the bundles of the cerebral peduncle in scattered strands to nucleus subthalamicus, which is a lens-shaped nucleus lying above the peduncle.

Nucleus tractus optici basalis in the bat has an unusually intimate relation to the surrounding structures in the region, presumably because of the curious crowding in this area. The cells making up this nucleus are dominantly oval, mediumsized, multipolar cells with a few intermingled small neurons. The cells stain rather deeply, consequently the nucleus is easily distinguished in the field. The cell nucleus is large with a prominent nucleolus. These neurons are similar to cells of substantia nigra, which is not large in the bat.

In addition to the connection of the anterior accessory optic tract with nucleus subthalamicus and of tractus opticus basalis with the capsular portion of nucleus interpeduncularis, primary optic fibers of tractus opticus basalis may be traced to the reticular gray (tractus optico-reticularis accessorius) and to substantia nigra (tractus optico-nigralis accessorius) in the silver preparations (see fig. 1A). Fibers from tractus opticus basalis, as well as fascicles originating in nucleus tractus optici basalis, cross to the nucleus of the contralateral side through the supramammillary decussation, and other small bundles terminate in the oculomotor nucleus. Some of the fibers seem to join the fascicles of the oculomotor nerve and to pass dorsalward with them.

C. Xantharpyia amplexicaudata. The brain of the fruit bat is larger than those of the insectivorous bats; it is approximately the size of the white rat brain, which it resembles closely in other respects also.

Nucleus tractus optici basalis is located at the base of the midbrain, between the posterior portion of the mammillary body medially and the medial end of the cerebral peduncle ventrolaterally. The nucleus is fairly large and somewhat oval in shape. It receives fibers from tractus opticus basalis and the mammillary peduncle, and commissural fibers from the 
opposite side through the supramammillary decussation. The other connections of the nucleus, which are probably similar to those in other chiropteres, cannot be determined from this material.

In Xantharpyia amplexicaudata there is also another group of small cells that undoubtedly belongs to nucleus tractus optici basalis and which lies among the fibers of tractus opticus basalis just before these latter turn dorsalward into the terminal nucleus. In this particular animal the secondary group of cells is large enough to form a distinet hump on the ventral surface of the brain. This small group of cells is found in some animals and not in others included in this study. It is concluded, therefore, that it is not a separate nucleus but is composed of neurons which have retained their primitive position as the rest of the nucleus was pushed dorsalward by the peduncle in its growth along the lateral wall. These two groups of nucleus tractus optici basalis were found in the guinea pig by Wallenberg ('04) and in the cat material studied. For discussion see page 386 below.

The fibers making up tractus opticus basalis are more thinly medullated than those of the optic tract. The number of medullated fibers seems to be somewhat less than in the rat brain which is comparabble in size and more than in the other bat brains, but the proportion of unmedullated fibers in the system cannot be determined from the material at hand.

Surprisingly enough, that portion of tractus opticus basalis which runs below the peduncle may be seen in sections caudal to the actual level of termination of the tract. It is a very distinct bundle of fibers that forms a small eminence on the surface of the brain, and it can be traced dorsalward to a position at the dorsolateral tip of the peduncle ventral to the medial geniculate body. It is probable that tractus opticus basalis has reached this position in relation to the medial geniculate from the chiasma region by passing in company with fibers of the optic tract, although this is not determinable from the sections since the fibers cannot be differentiated from those of the peduncle. 
Suzuki ('36, p. 883) after reading this same series of sections reported that "tractus peduncularis transversus externus" (tractus opticus basalis of this paper) is a tract having its cells of origin in nucleus tractus optici basalis. He traced the bundle over the ventral surface of the peduncle to the caudal pole of the medial geniculate body. The basal optic root, according to him, is a separate tract, which termi nates in nucleus tractus optici basalis. "Curiously enough," Suzuki stated, "the basal optic fibers ending in this nucleus are very difficult to trace, while the tractus peduncularis transversus arising from it is very distinct, so that I agree with Frey ('35) in considering the latter not as a continuation but as a secondary neurone of the basal optic system."

It is possible that we do not understand Suzuki's interpretation of this series, but the material is not sufficiently clear for us to determine whether tractus opticus basalis does end in the caudal pole of the medial geniculate nucleus or whether it runs forward to join the optic tract. Some experimental work is necessary to settle the course of these fibers, but in the light of the experiments carried out for this study on other forms it is reasonable to suppose that the pattern in the fruit bat is similar to that in other chiropteres. In examining this series a second tract (which Suzuki calls the basal optic tract) terminating in the nucleus of the basal optic root could not be located; there is only one bundle in this particular series which terminates in this nucleus, tractus opticus basalis, according to the present interpretation.

Tractus opticus basalis is present in chiropteres and has its origin in the retina as proved by the experimental work on Eptesicus fuscus fuscus. The fibers cross almost completely in the caudal portion of the optic chiasma and accompany the optic tract to a region ventral to the medial geniculate nucleus. At this point the tract separates from the optic tract proper and courses below the cerebral peduncle to terminate in nucleus tractus optici basalis. This nucleus is located between the medial end of the peduncle on one hand and the mammillary body and nucleus interpeduncularis on 
the other in the small-eyed bats and slightly more rostrally in the fruit bat. Various secondary fibers connect nucleus tractus optici basalis with such midbrain nuclei as substantia nigra, the oculomotor nucleus, the reticular gray and the contralateral nucleus of the basal optic tract. The primary neurons make connections with nucleus interpeduncularis, the oculomotor nucleus, and possibly other areas.

The anterior accessory optic tract is discernible in much of the normal material, its presence being substantiated in the experimental preparations. This tract passes up through the peduncular fiber bundles as scattered fascicles of varying size to nucleus subthalamicus.

Tractus opticus basalis is very thinly medullated in the small-eyed forms and only slightly more medullated in the large-eyed form. It is possible that the degree of medullation is an indication of the amount of functional development of the accessory optic systems in chiropteres.

\section{Insectivora}

Blarina brevicauda. According to Le Gros Clark ('33), a characteristic feature of a number of insectivores is the very small optic nerves and tracts which are associated with a small lateral geniculate body, in which the ventral nucleus is the larger and the dorsal nucleus is poorly developed. Blarina brevicauda, a common American shrew, belongs to the group of insectivores which have a small optic system. Microscopically the optic chiasma and tracts are detectable on the ventral surface of the brain, but they cannot be seen macroscopically if the slide is held up to the light. The fibers of the supra- and postoptic commissures, which run dorsal and caudal to the optic tract, increase the size of the chiasma and of the tract as the latter swings dorsocaudally around the brain stem. The majority of the fibers from the optic tract proper terminate in the lateral geniculate body with only a few extending to the superior collicular region.

Tractus opticus basalis is a small bundle of fibers which may first be seen clearly in the transverse sections as it turns 
off the optic tract just ventral to the medial geniculate body and courses caudally and medially to the level of the posterior third of the mammillary body. At this level the fibers swing dorsalward to terminate in nucleus tractus optici basalis, which lies caudal to nucleus subthalamicus and in the same relative position with respect to the medial tip of the cerebral peduncle (fig. 2D).

The cells of nucleus tractus optici basalis resemble those of substantia nigra, but are set off in a more compact and well-defined group at the medial end of the cerebral peduncle. The cells are medium-sized, multipolar neurons, which stain rather deeply and have a large nucleus.

The caudal portion of nucleus subthalamicus in the shrew lies just dorsal to the medial end of the peduncle. At this level fibers from tractus opticus basalis extend up through the medial tip of the peduncle to enter nucleus subthalamicus (fig. 2B). Still more caudally, a few fibers come from below the peduncle and enter the fibrous capsule of nucleus interpeduncularis (fig. 2C), which is posterior to nucleus tractus optici basalis.

The anterior accessory optic tract leaves tractus opticus basalis as the latter courses below the cerebral peduncle; it penetrates this latter bundle of fibers and enters the lateral tip of nucleus subthalamicus (fig. 2A). The anterior tract is fairly compact and does not break up into a number of small fascicles as it crosses through the peduncular bundle. It is also possible to consider the fibers (mentioned above) which penetrate the medial end of the peduncle and enter the caudal and medial portion of nucleus subthalamicus as belonging to this anterior accessory optic tract. There can be no doubt from the material at hand that this tract is associated with tractus opticus basalis and with nucleus subthalamicus.

These accessory optic tracts are small. However, in comparison with the optic tract fibers, which are greatly reduced, they are relatively large. From this study, then, and from a study of brains of mice with defective eyes, it may be concluded that the reduction in size of the accessory optic tracts, 
especially of tractus opticus basalis, is not proportional to the reduction in size of the optic tract. It is somewhat suggestive that the reduction occurs first in the optic fibers in the conscious pathway which is added last phylogenetically and is a modifiable system. The reflex mechanism, which is primitive

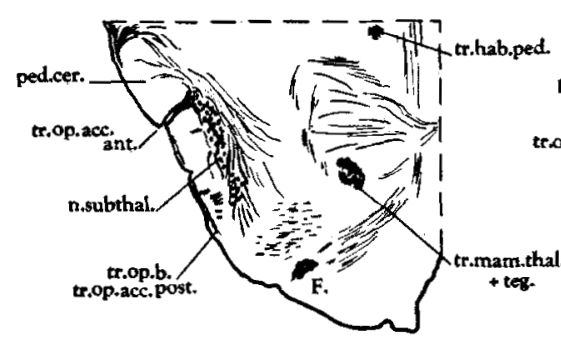

$\mathbf{A}$

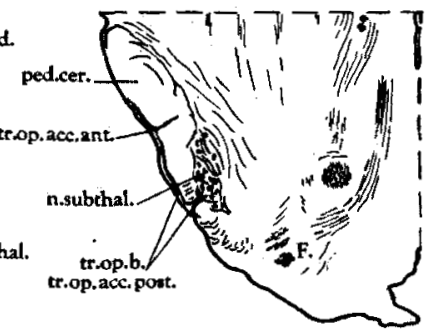

B

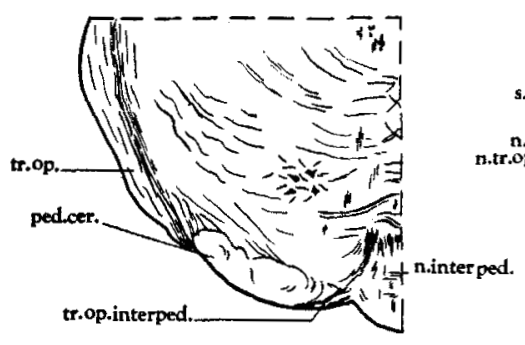

$\mathrm{C}$

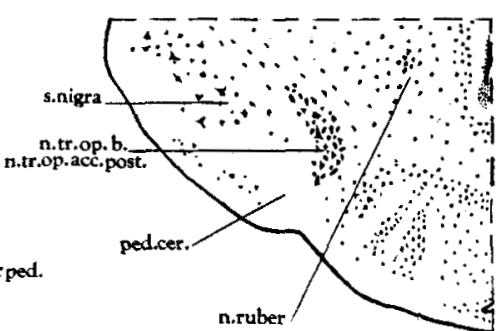

D

Fig. 2 Transverse sections of the brain of Blarina brevicauda. $\times 20 . A$ and B. Pyridine silver sections showing the connections of the anterior accessory optic tract with nucleus subthalamicus. C. A pyridine silver section showing tractus optico-interpeduncularis. D. A toluidin blue section showing the position of nucleus tractus optici basalis in the most anterior part of the midbrain.

and protective, is more stable and is the last to be affected by a reduction in the optic fiber systems. In any case both the tectal connections and the basal optic root are proportionately less reduced than the optic tract in chiropteres. 


\section{Rodentia}

Considerable investigation has been done on tractus opticus basalis in rodents, especially in the rabbit by Pavlow ('00) and Münzer and Wiener ('12), and in the rabbit and the rat by Kosaka and Hiraiwa ('15). Gurdjian ('27) observed this tract in the rat, and Wallenberg ('04), Castaldi ('23), and Frey ('35, '37) have reported it in the guinea pig. The tract has its origin in the retina of the eye and degenerates upon enucleation of the eye or upon cutting the optic nerve; substantiation of this fact is found in the reports of Pavlow ('00), Loepp ('12), Kosaka and Hiraiwa ('15), and Brouwer ('23).

A. Mus norwegicus. The white rat was found to be a convenient experimental animal to use for the typical rodent. The brain is small enough to fix and run up for sectioning in a short time and yet large enough to use experimentally with a reasonable degree of accuracy. The eyes and optic tracts are well developed and in average proportion to the rest of the brain, even though the rat is an active nocturnal animal.

The bundles making up the optic tract in the rat are heavily medullated. At the chiasma the majority of the fibers cross, although there are some which do not. The fibers run laterally and dorsally in a compact bundle and terminate for the most part in the dorsal part of the lateral geniculate body and in the optic tectum.

The fibers of the basal optic root accompany those of the optic tract and cross in the caudal portion of the optic chiasma. This basal optic tract is relatively easy to follow in the normal Weigert or Weil preparations and can be seen in its ventrocaudal position to leave the optic tract at the ventrocephalic tip of the medial geniculate body. It then runs medially and caudally below the cerebral peduncle, at the medial tip of which it turns dorsolateralward to end in nucleus tractus optici basalis (fig. 3A). In this animal the fibers of tractus opticus basalis do not separate from the optic tract in a compact bundle but leave in small fascicles, which later join to make a well-defined and compact fiber bundle in the latter half or one-third of its extent. 
Gurdjian ('27) reported that tractus opticus basalis was identifiable in its terminal portion but that in the normal material he could not trace the tract to the optic nerve. Le Gros Clark ('32) described briefly the course and termination of this tract in a rat brain stained by Marchi technique following experimental lesions. He gave an interesting figure (see Le Gros Clark, '32, fig. 6) of the course of the anterior and posterior accessory optic tracts in a typical mammalian brain. By far the larger part of the fibers making up tractus opticus basalis in the rat are finely myelinated, so that in our silver material only the caudal portion of the tract is sufficiently well stained to be picked out.

Nucleus tractus optici basalis (fig. 3B), which receives the basal optic root fibers in the rat, lies caudal to nucleus subthalamicus, medial to the cerebral peduncle and substantia nigra, and lateral to the caudal portion of the mammillary body. It is equivalent to nucleus ectomamillaris of Gurdjian ('27) for the rat and of Wallenberg ('04) for the guinea pig. The nucleus is elongated and has its long axis in a slightly dorsolateral to ventromedial direction. The terminal fibers of the tract form a dense feltwork throughout the nucleus.

The cells of the nucleus are, for the most part, mediumsized with some small cells. The small ones have a large pale nucleus with a prominent nucleolus, although the nucleolus in the larger cells is not so conspicuous and the nucleus is often very long, corresponding to the shape of the cell. The most outstanding feature of these multipolar cells is the elongation of the greater part of them, and their long axis lies in the same direction as does that of the entire nucleus. The cells are deeply stained and more closely grouped than those of the pars compacta of substantia nigra, which lies immediately at the dorsolateral tip of the nucleus and consists of unusually large neurons in this animal.

The Marchi preparations of the experimental material in which one eye was destroyed showed complete degeneration in the optic nerve on the enucleated side. Posterior to the chiasma the greater part of the degeneration appeared on the contra- 
lateral side with a little on the homolateral side. Tractus opticus basalis showed the Marchi granules on the side opposite the enucleation but none on the same side; it can, therefore, be concluded that this tract is entirely crossed in the rat (fig. $3 \mathrm{C}$ ).

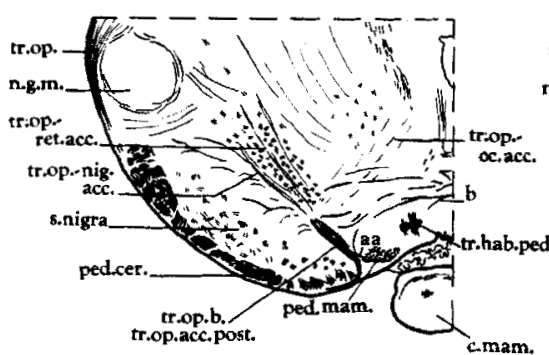

A

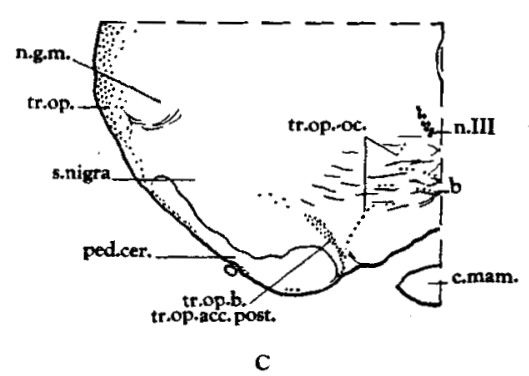

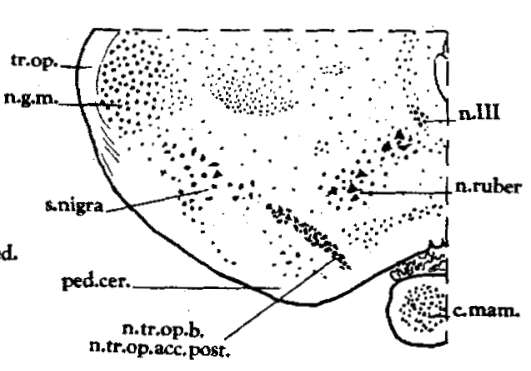

B

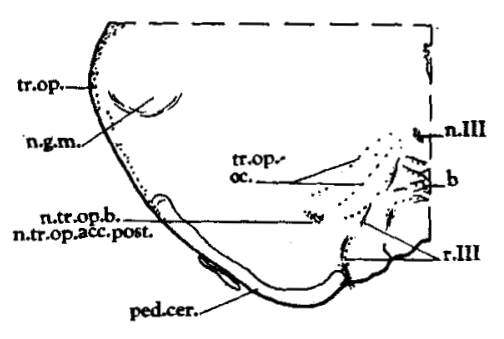

D

Fig. 3 Transverse sections through the anterior portion of the midbrain of the albino rat. $\times 10$. A. A Weil section showing the terminal fibers of tractus opticus basalis and secondary conneetions of nueleus tractus optici basalis. B. A toluidin blue section adjacent to $A$, showing the position and relations of nucleus tractus optici basalis. $\mathrm{C}$ and $\mathrm{D}$. Marchi preparations showing the degeneration of the primary optic fibers and part of their distribution to the nuclear centers.

Some attempts at total degeneration of tractus opticus basalis, with subsequent staining of the series by the Weil method, were not entirely successful. The tract on the contralateral side showed a reduction in the total number of fibers after 45 days, enough so that the contrast with the 
normal side was evident. By staining every second section of this brain with toluidin blue it was possible to locate and identify nucleus tractus optici basalis beyond question (fig. $3 \mathrm{~A}$ and $\mathrm{B})$. Every third section was stained by the Bodian silver method, and these furnished adequate data for determining accurately the terminations of the fibers of the tract. The greater part could be seen to end on cells of nucleus tractus optici basalis. That these were the terminal fibers had proof in the fact that the terminal pericellular arborizations of the neuraxones were plainly visible. A few of the fibers were seen to pass through the nucleus and turn ventrally and dorsally to end on the larger cells of substantia nigra (see also Le Gros Clark, '32).

In addition to tractus optico-nigralis, there are other fibers of tractus opticus basalis which pass through the nucleus and continue in a dorsolateral direction, coursing very close to the lower border of the medial lemniscus, to enter the lateral reticular gray of the midbrain region. It is quite unlikely that these fibers join the medial lemniscus as the Marchi degeneration series, as well as the normal preparations, show them entering the reticular area without joining the lemniscus.

Primary optic fibers also pass independently, and with fascicles of the oculomotor nerve, through nucleus tractus optici basalis, to the oculomotor nucleus (fig. 3D). Marchi granules could be traced to the nucleus and a few were found in it. Other primary fibers cross the midline in the supramammillary decussation (commissure of Forel) and probably end in the contralateral nucleus tractus optici basalis, although the Marchi granules could not be followed farther than just across the midline (fig. $3 \mathrm{C}$ and $\mathrm{D}$ ).

Secondary connections from nucleus tractus optici basalis pass to substantia nigra, the reticular formation, and the oculomotor nucleus. Others join the relatively more numerous primary fibers to these midbrain nuclei (fig. 3A). Still other fascicles from the nucleus of the basal optic tract join the supramammillary decussation. 
A small bundle of primary fibers can be traced to the fibrous capsule of the interpeduncular nucleus in the normal silver sections and also very faintly in the Marchi series. However, the connection is not so conspicuous as it is in the bat and in the shrew.

Just medial to nucleus tractus optici basalis, between it and the mammillary body, is the mammillary peduncle, an ascending tract in part, at least, from the visceral centers of the brain stem. Fibers can be seen to run between this tract and nucleus tractus optici basalis, but the direction of conduction could not be determined (fig. 3A).

The anterior accessory optic tract in the rat is very difficult to identify in normal brain sections. Indeed, Gurdjian ('27) stated that he could not identify it at all, and Kosaka and Hiraiwa ('15) believed that it is not well developed in this form. Le Gros Clark ('32; see also his fig. 6) identified this tract but could not follow it to its termination. Our experimental material shows this tract to be present in the white rat. The neuraxes run in the same bundle as those of tractus opticus basalis until, as scattered fibers, they are seen to penetrate the peduncle and enter the ventrolateral portion of nucleus subthalamicus. The number of fibers making up this tract apparently varies from animal to animal, but the system is never so well developed here as in some chiropteres and insectivores.

$B$. Mus domesticus. Some pyridine silver sections of brains of normal mice and mice with defective eyes were available for study at the University of Michigan. The defect was either unilateral or bilateral but there was never complete blindness, and the chief result was a reduction in size of the optic tract or tracts.

The basal optic root or tractus peduncularis transversus is present in both groups of mice and leaves the optic tract proper to follow the same course below the peduncle as described for the rat. Nucleus tractus optici basalis lies medial and slightly dorsal to the medial tip of the peduncle and lateral to the mammillary body. The connections of nucleus 
tractus optici basalis are similar to those of the corresponding nucleus in the rat.

In those mice with both eyes defective, tractus opticus basalis is smaller than in the normal mice, though proportionately not so greatly reduced in size as is the optic tract. Brouwer ('23) found that the fibers of tractus opticus basalis are not uniformly distributed in the retina, so that apparently it depends upon the retinal area destroyed (or defective) as to how much reduction there may be in tractus opticus basalis.

C. Cavia cobaya. Tractus opticus basalis is especially well medullated in the guinea pig and can be traced without any difficulty in its course below the peduncle to its termination in nucleus tractus optici basalis. The majority of the fibers end in a relatively large nuclear mass located dorsomedial to the medial tip of the peduncle at levels through the caudal pole of the mammillary body and behind it. At the point at which the tract turns dorsolaterally the fibers spread out, forming a round bulge, to accommodate, at the medial tip of the peduncle, a small group of cells which comprises a part of nucleus tractus optici basalis. Although toluidin blue sections were not available for study, the nuclear arrangement as it could be determined from the Weigert series appears to be similar to that found in the fruit bat (Xantharpyia amplexicaudata) and the cat. Wallenberg ('04) described two portions of this nucleus in his study of the guinea pig; the dorsolateral group of cells he termed "ganglion ectomamillare dorsalis" and the ventral group "ganglion ectomamillare ventralis." A small band of cells connects the two nuclear masses. The form and position of the ventral nuclear mass, as Wallenberg stated, are similar to the ganglion ectomamillare of birds (Huber and Crosby, '29). Undoubtedly this was the embryonic position of nucleus tractus optici basalis, and as the main group of cells was shifted to its dorsolateral position with the downgrowth of the peduncular fibers, a small number of the cells retained the original relationship. In most of the other mammalian forms studied, the entire nucleus has shifted in the course of development. 
In so far as the material available would permit, the connections of nucleus tractus optici basalis in the guinea pig are similar to those in the rat. Fibers could be traced going toward the oculomotor nucleus and toward the reticular formation near the red nucleus and ventral to the medial lemniscus. There is a connection between the nucleus and substantia nigra on the one hand and the mammillary peduncle on the other. Marburg ('03 a) found tractus opticus basalis in the guinea pig, and Castaldi ('23) reported tractus opticus basalis and its terminal nucleus. The latter also found an anatomical component between the nucleus and substantia nigra.

At the caudal end of tractus opticus basalis, after the main mass of fibers have turned up into nucleus tractus optici basalis, there is a small bundle which keeps its position at the base of the peduncle. As the most rostral fibers of the oculomotor nerve cross the region between nucleus interpeduncularis and the peduncle, the tract moves medially and contacts the fascicles of the oculomotor nerve. Beyond this point it is impossible to trace the tract in the series at hand.

D. Sciurus vulgaris. The brain of the squirrel is in the size range of that of the guinea pig, and the optic tract is large and heavily medullated. Tractus opticus basalis can be traced from the lateral tip of the cerebral peduncle (where it leaves the ventrocaudal portion of the optic tract) continuously in a single section to the medial end of the peduncle where it turns into nucleus tractus optici basalis. It is very large and well medullated, and even in the normal brain there can be no doubt as to the origin of the fibers.

As the fibers of tractus opticus basalis turn dorsolateralward around the tip of the peduncle, they fan out to form a feltwork in which the cells of the terminal nucleus lie. A few cells are seen in the ventral position, but the greater part of the nucleus lies somewhat more dorsal and lateral. The caudal third of the mammillary body and the mammillary peduncle lie medial to it. The cells of the nucleus are chiefly medium-sized with a few large neurons and are closely packed in the terminal portion of the basal optic root. 
The connection between the mammillary peduncle and nucleus tractus optici basalis is very plain in this series. Some of the fibers from the tip of the terminal cone of tractus opticus basalis turn medially and pass dorsalward through the red nucleus and are then lost in the dense mass of fibers about this nucleus. A small bundle of medullated fibers can also be traced to nucleus interpeduncularis from nucleus tractus optici basalis, but whether these are primary or secondary neurons could not be determined. No anterior accessory optic tract could be identified from this series of the squirrel brain.

Frey ('37, p. 38) disagreed with the Marburg ('03 a, '03 b) interpretation that tractus peduncularis transversus of higher mammals is homologous with the basal optic root in birds and reptiles, "sondern als eine sekundäre Verbindung aus dem Endkern derselben aufgefasst werden muss. Eine andere sekundäre Verbindung aus dem gleichen Kern stellt dann nach unserer Auffassung der innere (medialle) Schenkel des Tractus peduncularis transversus dar, der Beziehungen zur medialen Schleife und zur Substantia nigra hat."

Further along Frey ('37, p. 38) stated that the classical tractus peduncularis transversus described by Ariëns Kappers "nicht mehr die basale optische Wurzel im engeren Sinne darstellen, sondern als sekundäre Verbindungen aus dem basalen optischen Kern, Endstätte der eigentlichen basalen Optikuswurzel, angesehen werden dürfen."

Frey has based his statements primarily upon the picture presented in the horizontal sections of the guinea pig brain without due regard for the frontal series. We do not agree with him that there are two tracts. If our interpretation of his paper is correct, the secondary bundle, which he called the real tractus peduncularis transversus, is that portion of the basal optic root passing through the nucleus optici basalis and distributing to the lateral reticular region.

Frey stated that he obtained a degeneration of the secondary fibers, his tractus peduncularis transversus, because their cells of origin had degenerated secondarily as a result of the destruction of the basal optic root. "In diesem Falle wäre es 
zu erwarten, dass bei einer Läsion des Optikus eine totale Degeneration des gekreuzten basalen optischen Kernes eintritt'" (Frey, '37, p. 30).

It is true that after long degeneration of a tract the nucleus of its termination will undergo chromatolysis from disuse, but this process requires many months or even years, and it would not be evident in the few days' time required to prepare material for the Marchi method. Since the nucleus has other connections, it would not be totally degenerated in any case. Kosaka and Hiraiwa ('15) did not find any chromatolysis in nucleus tractus optici basalis after enucleation of the eye in the rat, rabbit, guinea pig or dog. It is evident then that the degenerated tract which Frey found in his Marchi material was the basal optic root or tractus peduncularis transversus, a primary tract originating in the retina. Tractus opticus basalis (or tractus peduneularis transversus) has no primary connection with the superior colliculus or with the medial geniculate body.

Frey is quite correct in his statement that "Wir haben nachgewiesen, dass der Hauptbestandteil der Fasern des ventral von der Commissura Gudden liegenden optischen Bündels sich zum basalen optischen Kern begibt und dass nur vereinzelte Fäserchen in die Richtung des Corpus Luys, im Sinne Bochenek's abgehen" (Frey, '37, p. 38). The anterior accessory optic tract is smaller than the posterior tract. It may accompany the posterior tract until the former turns up through the peduncle to nucleus subthalamicus, and there is not any reason for recognizing the two tracts as discrete bundles with distinctly separate terminations. Therefore, we do not agree with Frey's statement immediately preceding the one quoted above to the effect that: "Aus unseren Ausführungen über die charakteristischen Eigenschaften der basalen optischen Wurzel und ihrer Lageverhältnisse in bezug auf den Tractus opticus and die Commissura Gudden ergibt sich von selbst, dass die basale Wurzel eigentlich dem grössten Teil des Fasciculus accessorius optici anterior Bochenek's (1908) entspricht'” (Frey, '37, p. 38). 
Tractus opticus basalis, as found in the rodent, is typical in pattern and in its connections. Rather extensive experimental work has provided proof for the retinal origin of this tract and the distribution of some of its primary fibers to the various midbrain nuclei, and careful study of the various other preparations has shown that there are secondary connections, even greater in number, from nucleus tractus optici basalis to these same nuclei. The one outstanding difference in the rodents is that tractus opticus basalis is much more heavily medullated than in any of the other groups studied.

\section{Carnivora}

The cat (Felis domestica) was selected as the representative carnivore for this comparative study on the basal optic root. The eyes of the cat are well developed, and the optic nerves and tract are relativ 'y large and heavily medullated. At the chiasma the nasal fibers cross and the temporal fibers are, for the most part, uncrossed; there are more crossed fibers than uncrossed, however. The majority of the optic fibers terminate in the dorsal nucleus of the lateral geniculate body. Some of the optic fibers go to the pretectal and tectal areas for termination.

The basal optic root has been reported in the cat by several observers, including Marburg ('03 a), Kosaka and Hiraiwa ('15), Brouwer ('23), and Rioch ('29 a, '29 b, '31), and in the dog by von Gudden (1881), von Monakow (1889), Kosaka and Hiraiwa ('15), and Rioch ('29 a, '31). Rioch ('31) also reported the tract in the aevisa, a small West African carnivore. Papez ('29) indicated the position of the tract on the gross brain of the cat, but his description of its course is not entirely correct.

In the pyridine silver series of cat brains it has been possible to identify tractus opticus basalis in the caudal portion of its course below the cerebral peduncle. The fibers at this point are for the most part unmedullated and therefore stain differentially in the silver material. The tract turns dorsally at the medial tip of the peduncle and terminates in 
nucleus tractus optici basalis (fig. 4A). Some of the fascicles seem to cut across the peduncular bundles as they approach the terminal nucleus.

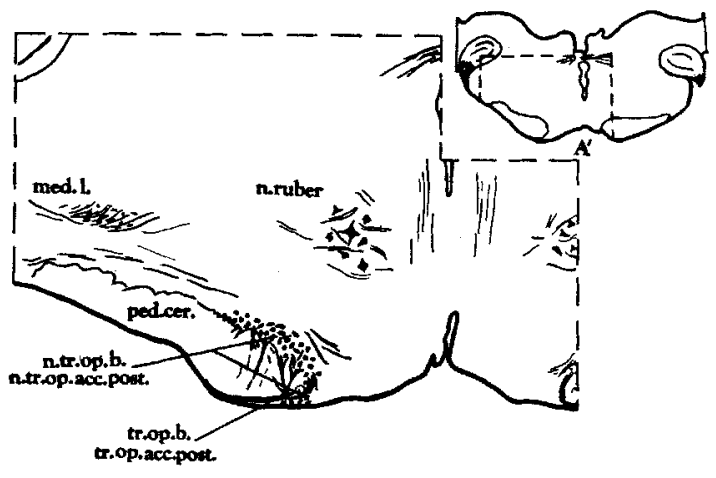

A

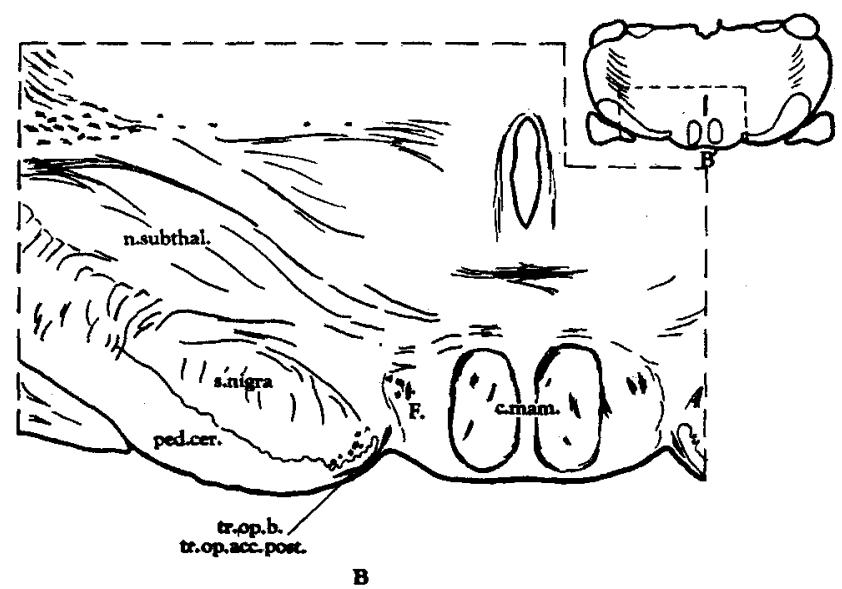

Fig. 4 A. A transverse section through the midbrain of the cat to show nucleus tractus optici basalis receiving the fibers of tractus opticus basalis. Pyridine silver. $\times 7 \frac{1}{4}$. A $A^{\prime}$, A diagram for orientation of A. B. A transverse section through the midbrain of Macaca mulatta illustrating the position and relation of the terminal portion of tractus opticus basalis. Weil. $\times 7 \frac{1}{2}$. B'. A diagram for orientation.

In the Weil series only the most caudal portion of the tract near the tip of the peduncle could be determined beyond question. The fibers here are fine and very thinly medullated, and 
even these do not appear in any great number. A very small band of fibers continues medially along the ventral wall to the mammillary peduncle. Some others course dorsolaterally to the lateral reticular area, and a few seemed to go dorsomedially in the direction of the oculomotor nucleus. These latter were very soon lost and their destination was undetermined. Only an indication of the place at which tractus opticus basalis leaves the main optic bundle could be found and this was evidenced only by a few faint fibers turning dorsomedialward at the dorsolateral tip of the peduncle along the ventral aspect of the medial geniculate body. Similarly the course of tractus opticus basalis below the peduncle was indicated by a very small clear area in places in which a fiber or two could be seen running ventromedially.

The above findings were confirmed by the experimental study. In the Marchi degeneration series, there was no conclusive evidence of a tractus opticus basalis. Through the lower portion of the peduncle were scattered a few very fine granules. From the observations made on the silver and Weil series, it is concluded that the majority of the fibers making up this tract are unmedullated and those that are medullated have so thin a myelin sheath that only occasional fine Marchi granules would result on degeneration.

However, nucleus tractus optici basalis was relatively easy to locate in the toluidin blue series. The nucleus lies caudal to the mammillary body immediately anterior to the emergence of the oculomotor nerve. It is fairly well developed and consists of a dorsal group of cells, somewhat oval in shape, at the dorsomedial tip of the peduncle medial to substantia nigra, and a smaller group of cells just ventral to the medial tip of the peduncle. The two groups are connected by a few scattered neurons. For the same reasons discussed previously with reference to the guinea pig, these two cell groups are considered to be a single nucleus separated during the course of development of the cerebral peduncle. Kosaka and Hiraiwa ('15) reported this separation of the nuclear elements in the dog also. 
The cells of the nucleus are medium-sized, multipolar neurons, which tend to be oval in shape. They are smaller and more deeply stained than those of substantia nigra. The cell nucleus is large and follows the shape of the cell body; the nucleolus is very large and conspicuous. The cells in the ventral portion of the nucleus below the peduncle are very few in number and are the same type as those in the dorsal group.

Rioch has shown nucleus tractus optici basalis (nucleus tractus peduncularis transversus) and the terminal portion of the basal optic root in figures 11 to 13 of his 1929 paper and in a second paper (' $29 \mathrm{~b}$ ) in figure 2 ; in the 1931 account he indicated the position of the tract in figures 7 and 8 , although it is doubtful if the bundle was any better medullated in the dog than in the cat series which we have used. In this same paper ('31, p. 364) he stated that "At the dorsal margin of the peduncle a group of fibers turns caudalward out of the posterior border of the optic tract, forming the posterior accessory optic tract of Bochenek (figs. 7, 8, 13)." In 1934 Rioch denied the evidence presented in his three earlier papers by saying (p. 84), "The tractus peduncularis transversus does not connect with the optic tract, but joins fibers running laterally over the brachium of the inferior colliculus to the third and fourth layers of the superior colliculus. These fibers apparently belong to a large lateral system connecting both colliculi with the substantia reticularis mesencephali and the nuclei pontis." In this last instance Rioch was undoubtedly attempting to locate tractus opticus basalis on the wrong side of the cerebral peduncle.

The anterior accessory optic tract could not be identified in any of the cat material available for study. There is no reason to suppose that there is no such tract in the cat, but it may be assumed that the fibers are either unmedullated or so very faintly medullated that they cannot be picked out. Judging from the findings regarding the anterior accessory optic tract in the other forms reported here, the fibers probably turn back from the optic tract with the posterior accessory 
group, subsequently penetrate the peduncle in scattered fascicles and terminate in the ventral portion of nucleus subthalamicus.

Rioch ('31, p. 363) described an anterior accessory optic tract in the eat, saying that as the optic tract "passes over the peduncle fibers leave its medial surface and mix with the fibers of Meynert's supraoptic commissure to run diagonally through the peduncle toward the zona incerta and the nucleus subthalamicus. The optic fibers cannot be further differentiated from the commissural fibers in the material available nor are the exact terminations apparent. These fibers represent the anterior accessory optic tract of Bochenek."

The optic fibers do not mix with the fibers of Meynert's commissure as evidenced by the Marchi degeneration series of the cat and in all other experimental material at hand. If no mixing of these fibers is apparent in the Marchi material, there is no reason to believe that there could be any in PalWeigert series, as this latter method also depends upon the medullated fiber for its staining properties. It can be safely concluded, therefore, that if there is no mixing of optic and commissural fibers there can be no anterior accessory optic tract in this position.

Nor should it be assumed that the anterior accessory optic tract can be seen more caudally at levels of the termination of the posterior accessory tract. The conspicuous bundles of fibers which penetrate the peduncle here are aberrant fascicles of cortico-tectal fibers (they can be traced to the tectum) and either strio-nigral or cortico-nigral fibers that go to substantia nigra at this level, posterior to nucleus subthalamicus in which the anterior accessory optic tract terminates.

In the second place it may be pointed out that Rioch ('31) was attempting to locate the anterior tract at the wrong level. The anterior accessory optic tract does not turn off the optic bundle as this latter is coursing below the cerebral peduncle but is given off just slightly more rostrally and ventrally than the posterior tract and from the ventral part of 
the optic system. The anterior bundle, then, runs caudalward before it turns up through the peduncle. This same error has been made by both Tsai ('25) and Chu ('32) in describing the anterior accessory optic tract in the opossum from normal material. For other descriptions in agreement with our interpretation the papers of Loepp ('12) and Pavlow ('00) should be consulted.

Barris and Ingram ('34) reported that corticofugal fibers could be traced to pontine nuclei by way of the transverse peduncular tract in the cat. Barris, Ingram and Ranson (' 35 , p. 140) identified "a bundle of fibers" (which they called the transverse peduncular tract) "passing from the occipital pole of the cerebral cortex along the ventral border of the basis pedunculi to the pons. . . . From the description given above, it is evident that it is not identical with the posterior accessory optic tract." This latter group failed to identify either the anterior or posterior accessory optic tract in the cat.

It may be concluded from this study that tractus opticus basalis does exist in carnivores. It is primarily an unmedullated tract and therefore only identifiable in silver material, and it has not been conclusively demonstrated in experimental material by available techniques at the present time. On the basis of a study of the course of a few faintly medullated fibers, it may be said that there are primary connections with the mammillary body, the lateral reticular area and probably the oculomotor nucleus. No connections from nucleus tractus optici basalis could be worked out from the material studied.

Although no anterior accessory optic tract could be identified, there is no reason to believe that it may not exist as unmedullated fibers which penetrate the cerebral peduncle in scattered fascicles.

\section{Ungulata}

Elephas indicus. The elephant has small eyes and the optic tract, although well medullated, is small in proportion to the rest of the brain. Tractus opticus basalis also appears small 
in the Pal-Weigert material, although this may be due to a limited number of unmedullated fibers. In general the tract follows the same pattern as in other mammals.

Nucleus tractus optici basalis lies dorsomedial to the tip of the cerebral peduncle and is small and more round than oval in shape. It lies well in front of the oculomotor nerve.

The anterior accessory optic tract could not be identified with any degree of certainty, although fibers could be traced from the region of the optic tract through the peduncle to nucleus subthalamicus.

\section{Primates}

In the monkey (Macaca mulatta) tractus opticus basalis may first be seen in the transverse sections as it crosses in the most caudal and ventral portion of the chiasma. The fibers are very thinly medullated and unmedullated and may, therefore, readily be distinguished from the heavily myelinated optic tract fibers. They separate from the main optic tract as this latter enters the lateral geniculate body and run medially and caudally below the peduncle. The separate course of tractus opticus basalis is relatively shorter in the monkey than in the lower mammals because of the more ventral position of the lateral geniculate body.

Nucleus tractus optici basalis is a fairly small, elongated cell mass that lies dorsomedial to the cerebral peduncle; its dorsal end is directed dorsolaterally, and the ventral tip, ventromedially. Substantia nigra, pars compacta, adjoins the nucleus immediately at its dorsal tip, and the mammillary body lies medial to the rostral portion of it. This nucleus has been described by Papez and Aronson ('34) for Pithecus (Macacus) rhesus.

The cells of the nucleus resemble those of nucleus tractus optici basalis in the rat. They are small and medium-sized neurons which are very much elongated. It is interesting to notice that if the nucleus is a long, thin band of gray, the cells tend to be very much elongated in the plane of the long axis of the nucleus. The cells are slightly smaller and longer 
than those of substantia nigra. The cellular nucleus is large but not conspicuous.

As in other forms, the tract takes a mediocaudal course below the cerebral peduncle after separating from the main optic tract. It then swings around the tip of the peduncle and terminates in nucleus tractus optici basalis. Further connections of tractus opticus basalis and of nucleus tractus optici basalis could not be determined nor could the anterior accessory optic tract be identified in the normal material.

In the Marchi degeneration material prepared after enucleation of the right eye, the basal optic root was visible as deeper staining fibers turning around the end of the cerebral peduncle at the level of the mammillary body. Very fine granules could be seen in the course of this tract as it rounded the tip of the peduncle on the left side. The right side showed practically nothing. The experimental findings agree with and confirm the observations made on the normal material, namely : the basal optic root is present but only thinly medullated. It is primarily a crossed path.

Tractus opticus basalis has been located by Kosaka and Hiraiwa ('15) in the monkey and has been found in the human embryo by Frey ('37). Marburg ('03 a) was able to trace tractus opticus basalis from the optic tract to its termination in nucleus tractus optici basalis in two human series, but von Monakow ('05) did not find it in man. In general the position of the nucleus is similar and the course of the tract is comparable to that found in lower forms (fig. 4B).

\section{GENERAL DISCUSSION}

The many and diverse names which have been applied to a single nucleus or tract have led to a complication and confusion of the terminology applied to the anatomy of many parts of the brain. In recent years there has been an effort made by various investigators to adopt new names which are descriptive and as brief as possible. It is hoped that a standard terminology will thus be evolved. For this reason the term tractus peduncularis transversus has not been used, because 
it does not indicate either the origin or termination of the tract and there are several tracts which cross the peduncle. The name tractus opticus basalis does indicate the optic origin and basal course and termination of the tract, and it has the further advantage of agreeing with the nomenclature applied to the reptilian and avian tract of which it is a homologue. Posterior accessory optic tract is not so objectionable, but it fits less well than tractus opticus basalis. The name anterior accessory optic tract has been retained for the tract going to nucleus subthalamicus because it is the only term found in the literature, and to introduce a new one would only be confusing.

Tractus opticus basalis has been found in all mammalian forms studied, including rodents, insectivores, chiropteres, carnivores, ungulates, and primates. See figure 5 for a general diagram of this system in mammals. The tract has its origin in the retina and is included with the optic tract until it reaches a position near the lateral tip of the cerebral peduncle. It crosses in the chiasma in a ventrocaudal position and may sometimes be distinguished from the main optic fibers at this place. After the tract turns caudally and medially to course below the peduncle it is relatively easy to follow its course as it swings around the medial tip of this fiber mass to terminate, for the most part, in nucleus tractus optici basalis. The fibers of the tract may be in a fairly compact bundle throughout their course, as they are in the shrew and some bats, or they may be spread out in a thin layer below the peduncle and then gathered into a compact terminal bundle as they are in rodents. The fibers of the tract are well medullated in rodents but the fact that they are less well medullated in the other forms makes it easy to understand why tractus opticus basalis has not been reported in some mammals and its existence denied in others.

Nucleus tractus optici basalis is a distinct group of cells located in the base of the midbrain in close relation to the medial tip of the cerebral peduncle. It would be difficult to overlook this nucleus in any cell-preparation series, even 
though its constituent elements are similar to those of substantia nigra in the shrew, bat, and cat. That this should be so is not unreasonable, since nucleus tractus optici basalis and

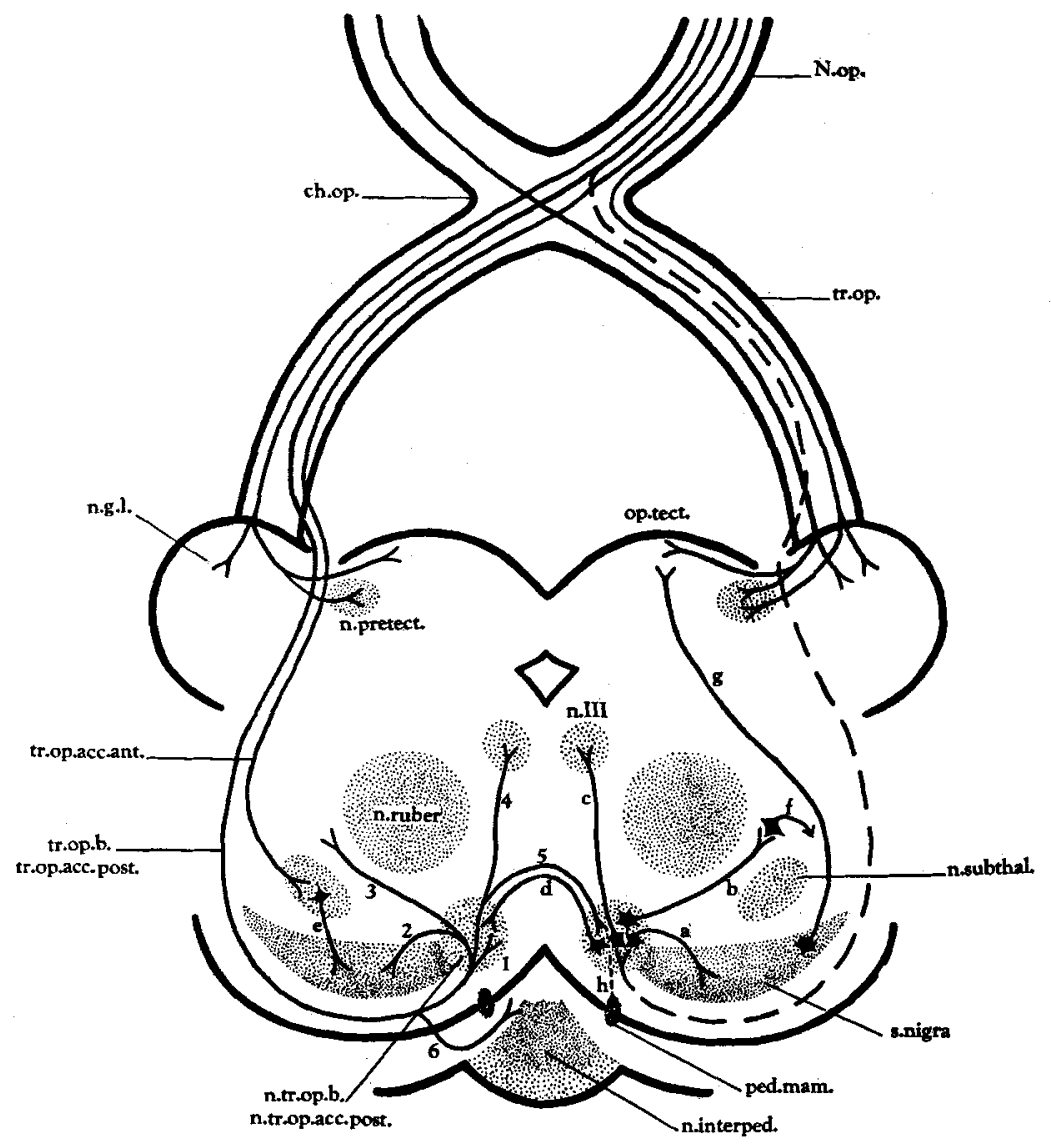

Fig. 5 A diagram showing the nucleus of the basal optic root with its principal connections and its relation to other nuclear structures in the diencephalo-mesencephalie region.

substantia nigra develop embryologically and phylogenetically from the same lateral gray mass. Nucleus tractus optici basalis is pushed ventralward by the developing substantia nigra and subsequently dorsalward by the downgrowth of 
the cerebral peduncle. In some cases (e.g., in the fruit bat, the guinea pig and the cat), the peduncle may divide the cells of the nucleus tractus optici basalis so that there is a ventral and a dorsal nuclear mass. So far as ean be determined this division has no functional significance and is merely a developmental accident.

So far as the material available for study has permitted, the distribution of the primary fibers of the basal optic root has been worked out. Especially helpful in this have been the several Marchi degeneration series prepared from experimental animals. The major connections have proved to be the same for all forms (fig. 5). The greater number of fibers of tractus opticus basalis terminate in the nucleus of the tract, and the secondary connections of this nucleus will be discussed below. Primary fibers end on the large cells of substantia nigra and thus constitute tractus optico-nigralis. Such a connection was reported by Sterzi ('14-'15). A fairly large number of fibers pass through nucleus tractus optici basalis and continue in a dorsolateral direction toward the lateral reticular area where they are lost. This bundle, tractus opticoreticularis, is especially conspicuous in the rodents, in which animals the fibers of tractus opticus basalis are deeply medullated and consequently show up well in both Weil and Marchi preparations. Some of the fibers pass immediately beneath the medial lemniscal system, but, judging from the Marchi sections, they never join the ascending sensory tracts. A few fibers could be traced to the neighborhood of the red nucleus, but again there was no direct termination on cells of this nucleus.

That some of the primary fibers of tractus opticus basalis reach the oculomotor nucleus was proved by our Marchi material. The fascicles pass dorsalward as scattered fibers, or at least in every small bundles, some of which may join the rootlets of the oculomotor nerve as they course through the midbrain. There are a few primary fibers which cross to the other side in the supramammillary decussation. 
The connections of nucleus tractus optici basalis are similar to those given above for the distribution of the primary fibers (see fig. 5). Fascicles can be traced to substantia nigra, the lateral reticular region, the oculomotor nucleus, and through the supramammillary decussation. There are relatively more fibers involved in the secondary pathway than in the primary connections with these midbrain centers.

In the shrew, the bat, and the rat primary fibers have been traced to the fibrous capsule of the interpeduncular nucleus. This bundle is more evident in the first two forms than in the rat. In addition, there appears to be a connection between the posterior accessory system and the mammillary peduncle. In the cat, fibers of tractus opticus basalis can be followed along the ventral wall of the brain stem to this bundle. In the lower forms the connection appears to be between the mammillary peduncle and nucleus tractus optici basalis, or at least with the very terminal portion of the tract. In these latter forms the direction of conduction of this pathway could not be determined.

Thus we may point out that the function of the accessory optic tracts is to establish a pathway of either one or, at the most, two neurons between the retina of the eye and various subthalamic and midbrain efferent centers, especially nucleus subthalamicus, substantia nigra, the oculomotor nucleus, and the midbrain tegmental gray. The nucleus of the basal optic root is a region of synapse between entering visual impulses and these efferent centers in the subthalamus and midbrain.

Very few of the previous investigators have enlarged upon the possible function of the accessory optic systems, but most of them agree that the two tracts have something to do with either visual or light reflexes. Shanklin ('33, p. 181) summarized its possible use in the chameleon by saying "The evidence suggests that the nucleus opticus tegmenti is under the influence of divers impulses, such as optic, auditory, and somatic. It may act as a correlation center, the output of which is partly responsible for the control of eye movements." Loepp ('12), however, was not clear in his own mind as to 
the meaning of tractus peduncularis transversus and the "Radix Luysiana," and he said that more experimental evidence would be required to determine if it be involved in pupillary reflexes. Lastly we quote from Rioch ('31, p. 366): “The close association of its (posterior accessory optic tract) nucleus of termination with the extrapyramidal system suggests that it is concerned with muscular coordination."

Some years ago Karplus and Kreidl ('09, '10) found that by stimulating electrically certain areas of the hypothalamus in the cat, they got a dilation of the pupil of the eye, a wider opening of the eyes, and a contraction of the nictitating membrane. They located this center in the medial and ventral part of corpus subthalamicus. Since light stimulation does not cause an increase in the size of the pupil, the role of the anterior accessory optic tract in the system explored by these two investigators is probably that of a regulator over these centers. Later Ingram, Ranson and Hannett ('31) found that dilation of the pupils could be obtained from many regions besides the subthalamic nucleus, especially the reticular substance in the tegmentum and many tracts near this area. "Whether the center for these reactions is a diffuse one," they said, "or whether descending pathways are activated by direct stimulation cannot be determined here. If the latter is true then the descending path must consist of widely scattered fibers."

It would be possible then to ascribe to the anterior accessory optic tract a regulatory effect over the functioning of nucleus subthalamicus since this tract enters the nucleus in its mediolateral and rostral portion. Again, the basal optic root ma-exert a similar regulatory action over the functioning of the reticular substance of the tegmentum.

The varying size of the accessory optic system and the degree of medullation found in this system in the different animals may have their basis in differences in habit and in the varying degree of importance played by the eyes in these animals. The bat has poorly developed eyes and, even at night when it is traditionally supposed to see better than by daylight, 
this animal must depend more upon its olfactory and auditory systems which are rather well developed and especially upon its vibratory sense. ${ }^{3}$ Nevertheless, the bat is a nocturnal animal and has a fairly large, though primarily unmedullated, accessory optic system. The rodents, on the other hand, have not only well-developed but also well-medullated accessory optic tracts. Rodents are notoriously active by night although they may be active by day. Some carnivores, ungulates, and primates are better known to perform by daylight.

Langworthy ('33, see also Langworthy, '29) found that the optic nerves of kittens and man have little or no myelin at the time of birth but become medullated when the eyes are open to receive stimuli. "It is the thesis of this paper," he wrote, "that beginning of myelinization of sensory pathways is dependent on the presence of adequate stimuli for the sensory ending and for the sensory cell." In conclusion he said that "in general tracts become medullated in the order of their phylogenetic development which also is the order of their importance in controlling the fundamental activities of the organism." Thus, since the medullation of a tract bears a relation to the functioning of the tract, we can see that the accessory system in rodents is more highly developed and more important than in the other forms. Since, too, the rodent is the one animal studied which is very active at night and has especially good vision then, we might suggest that the accessory optic pathways are used for visual reflexes which are made quickly to fairly indistinct objects.

In the bat, tractus opticus basalis and the anterior accessory optic tract are well developed but are only very thinly medullated. The accessory system could operate as suggested above for the rodents and thus provide a relatively more efficient reflex mechanism than the optic system. With the

\footnotetext{
${ }^{3}$ Hahn ('08) found that bats could avoid wires stretehed across a room better when blinded than when they could see. He attributed this to the vibratory sense which is located primarily in the sensory cells of the internal ear and secondarily to sense organs in the skin. Ackert ('14) believed these vibratory sensations to be perceived by the "free nerve end-knobs in the epidermis, but also in part by the superficial nerve rings of the hair follicles."
} 
main optic reflex system working in conjunction with the vibratory, olfactory, and auditory senses, the bat could well acquire the nocturnal dexterity for which it is well-known. Some carnivores ${ }^{4}$ and the primates studied who do their hunting by day would have little use for the accessory mechanism, and thus we find the system present but almost unmedullated. This observation agrees with a statement made by Brouwer and Zeeman ('25, p. 8) to the effect that "It is a well-established fact that in the ascending scale of mammals the number of the reflex fibres into the midbrain gradually diminishes, at least as far as they are myelinated." Tractus opticus basalis still has some use, however, or the entire system would probably have dropped out. Nucleus tractus optici basalis is distinct and easily recognizable in primates and persists as a good-sized nucleus after tractus opticus basalis is markedly small; this suggests that the nucleus is a correlation center. There is first a reduction in the optic connection, the major one, to this nucleus and then, phylogenetically, a reduction in the other connections. The accessory optic system, then, reaches the peak of development in rodents and decreases in size and medullation as well as in function thereafter.

\section{SUMMARY}

Nucleus tractus optici basalis has been found in all forms studied. It is a distinct gray mass located in the anterior portion of the midbrain at the dorsomedial tip of the cerebral peduncle, medial to substantia nigra and posterior to nucleus subthalamicus. Medially it is bounded by the posterior third of the mammillary body, and in some cases by the interpe-

\footnotetext{
"To the question "Do eats hunt at night"' most people answer very readily, "Yes, of course!" However, an examination of the literature reveals the fact that, although it is freely stated that cats "roam" and "hunt" at night, Forbush ('16) said that most of the actual kills are made at dusk or dawn and a considerable portion during daylight hours. Because of the lack of color vision in the cat's eye (Gates, '28) and because of the tapetum lucidum (Simpson, '03) eats have somewhat better vision in dim light, but their nocturnal vision is probably not so good as that of rodents. The vibrissae and the senses of hearing, touch and smell are great aids to the eat in hunting mice and rats in dark cellars (Forbush, '16).
} 
duncular nucleus. The oculomotor nerve usually emerges behind this nucleus, but in the insectivorous bat it crosses nucleus tractus optici basalis.

The principal afferent system to nucleus tractus optici basalis is tractus opticus basalis, a bundle of fibers having its origin in the retina of the eye. The efferent neurons from the nucleus distribute to various midbrain efferent nuclei including substantia nigra, the lateral reticular gray, and the oculomotor nucleus. A few of the primary neurons also reach these nuclei, and, in addition, go to the fibrous capsule of nucleus interpeduncularis. Both primary and secondary neurons cross the midline in the supramammillary decussation. In most of the forms studied there is a connection between the mammillary peduncle and the posterior accessory optic system.

The anterior accessory optic tract was identified in chiropteres, insectivores and rodents beyond any doubt but not in carnivores and primates. This tract also originates in the retina of the eye but terminates in the ventral and mediolateral portion of nucleus subthalamicus, after penetrating the fiber bundles of the cerebral peduncle.

The possible function of the accessory optic systems has been discussed, this discussion being based upon the distribution of the fibers, and the degree of development and medullation of these bundles correlated with the known habits of the animals.

\section{LITERATURE CITED}

ACKerT, J. E. 1914 The innervation of the integument of Chiroptera. J. Morph., vol. 25, pp. 301-343.

Arieins Kappers, C. U., G. Cari Huber and E. C. Crosby 1936 The cumparative anatomy of the nervous system of vertebrates including man. Macmillan Co., New York. Vol. 2.

ÄrNbäCk-Christie-Linde, A. 1900 Zur Anatomie des Gehirnes niederer Säugetiere. Anat. Anz., Bd. 18, S. 8-16.

Barris, R. W., AND W. R. INGRAM 1934 Optic connections of the midbrain and and thalamus. Anat. Rec., vol. 58, supplement, p. 3.

BARRIS, R. W., W. R. INGRAM AND S. W. RANSON 1935 Optic connections of the diencephalon and midbrain of the eat. J. Comp. Neur., vol. 62, pp. 117-154. 
Bochenek, A. 1908 Ueber zentrale Endigungen des nervus opticus. Anz. Akad. d. Wissensch. in Krakau. No. 1. Bull. Internat. Acad. Se. de Cracovie. Classe Se. math. et nat., pp. 91-95.

Brouwer, B. 1923 Experimentell-anatomische Untersuchungen über die Projection der Retina auf die primären Opticuszentren. Sehweiz. Arch. f. Neur. u. Psychiat., Bd. 13, s. 118-137.

Brouwer, B., AND W. P. C. ZEEMAN 1925 Experimental anatomical investigations concerning the projection of the retina on the primary optic centers in apes. J. Neur. and Psychopath., vol. 6, pp. 1-10.

Castaldi, L. 1923 Studî sulla struttura e sullo sviluppo del meseneefalo. Arch. Ital. di Anat. e di Embriol., vol. 20, pp. 23-225.

CHO, Ho-NIEN 1932 The fiber connections of the diencephalon of the opossum, Didelphis virginiana. Monographs of the National Research Institute of Psychology, Academia Siniea, No. 3.

Crark, W. E. Le Gros 1928 On the brain of Macroscelididae. J. Anat., vol. 62, pp. 245-275.

1932 The structure and connections of the thalamus. Brain, vol. 55, pp. 406-470.

1933 The brain of Inseetivora. Proc. Zool. Soc., London, January 1933 , pp. 975-1013.

Forbush, E. H. 1916 The domestic eat. Economic Biology, Bulletin No. 2. Boston.

Frey, E, 1935 Die basale optische Wurzel des Meerschweinchens. Proc. Kon. Akad. v. Wetensch., Bd. 38, S. 3-11.

1937 Vergleichend-anatomische Untersuchungen über die basale optische Wurzel, die Commissura transversa Gudden und über eine Verbindung der Netzhaut mit dem vegetativen Gebiet im Hypothalamus durch eine "dorsale hypothalamische Wurzel" des Nervus opticus bei Amnioten. Schweiz. Arch. f. Neur. u. Psychiat., Bd. 39, S. 5-98.

GANSER, S. 1882 Vergleichend-anatomische Studien über das Gehirn des Maulwurfs. Morph. Jahrb., Bd. 7, S. 591-724.

GATES, G. S. 1928 The modern cat: her mind and manners. Maemillan Co., New York.

Gilcilas, L. A. 1939 The connections of the nucleus of the basal optic root in various mammals. Anat. Rec., vol. 73, supplement, p. 21.

v. Gudden, B. 1881 Ueber den Tractus peduncularis transversus. Arch. $f$. Psych., Bd. 11, S. 415-423.

Gurdjian, E. S. 1927 The diencephalon of the albino rat. J. Comp. Neur., vol. 43 , pp. 1-114.

HAHN, W. L. 1908 Some habits and sensory adaptations of cave-inhabiting bats. Biol. Bull., vol. 15, pp. 135-193.

Huber, G. Carl, AND E. C. Crosby 1929 The nuclei and fiber paths of the avian diencephalon, with consideration of telencephalic and certain mesencephalic centers and connections. J. Comp. Neur., vol. 48, pp. 1-225.

HuMphrex, T. 1936 The telencephalon of the bat. J. Comp. Neur., vol. 65, pp. $603-711$.

Ingram, W. R., S. W. Ranson and F. I. Hannetr 1931 Pupillary dilation produeed by direct stimulation of the tegmentum of the brain stem. Am. J. Physiol., vol. 98, pp. 687-691. 
Karplus, J. P., and A. KReidL 1909 Gehirn und Sympathicus. I. Zwisehenhirnbasis und Halssympathicus. Arch. f. d. ges. Physiol. (Pflüger's), vol. 129 , S. 138-144.

1910 Gehirn und Sympathicus. II. Ein Sympathicuszentrum im Zwischenhirn. Arch. f. d. ges. Physiol. (Pflüger's), Bd. 135, S. 401-416.

Kosaka, K, AND K. Hiraiwa 1915 Zur Anatomie der Sehnervenbahnen und ihrer Zentren. Folia Neuro-Biol., Bd. 9, S. 367-389.

LANGWORTHY, O. R. 1929 A correlated study of the development of reflex activity in fetal and young kittens and the myelinization of tracts in the nervous system. Contrib. to Embryol., No. 114, Carnegie Inst., Washington, vol. 20, pp. 127-172.

1933 Development of behavior patterns of the nervous system in the human fetus and infant. Contrib. to Embryol., No. 139, Carnegie Inst., Washington, Publication No. 443, pp. 1-57.

Lospp, W. H. 1912 Ueber die zentralen opticusendigungen beim Kaninchen. Anat. Anz., Bd. 40, S. 309-323.

Marburg, O. 1903 a Basale Opticuswurzel und Tractus peduncularis transversus. Arbeiten aus dem Neurologisehen Institute an der Wiener Universität, Heft 10 , S. $66-80$.

$1903 \mathrm{~b}$ Basale Opticuswurzel und Tractus peduncularis transversus. Centralblatt f. Physiol., Bd. 17, S. 30.

v. Monakow, C. 1889 Experimentelle und pathologish-anatomische Untersuchungen über die optischen Centren und Bahnen. Arch. f. Psych., Bd. 20, s. $714-784$.

1905 Gehirnpathologie. 2. Aufl, Wien. (Quoted from Ariöns Kappers, Huber and Crosby, '36.)

Münger, E., AND H. WIEner 1912 Das Zwischen- und Mittelhirn des Kaninchen und die Beziehung dieser Teile zum übrigens Centralnervensystem, mit besonderer Berücksichtigung der Pyramidenbahn und Schleife. Monatschr. f. Psychiat. u. Neurol., Bd. 12, S. 241-279.

PAPEz, J. W. 1929 Comparative Neurology, Crowell, New York.

Papez, J. W., ANd L. R. Aronson 1934 Thalamic nuelei of Pithecus (Macacus) rhesus. Areh. Neur. and Psychiat., vol. 32, pp. 1-44.

Pavlow, W. 1900 Les connexions centrales du nerf optique chez le lapin. Le Névraxe, T. 1, pp. 237-246.

Rloch, D. McK. 1929 a Studies on the diencephalon of Carnivora. I. The nuelear configuration of the thalamus, epithalamus, and hypothalamus of the dog and eat. J. Comp. Neur, vol. 49, pp. 1-119.

$1929 \mathrm{~b}$ Studies on the diencephalon of Carnivora. II. Certain nuclear configurations and fiber connections of the subthalamus and midbrain of the dog and cat. J. Comp. Neur, vol. 49, pp. 121-153.

1931 Studies on the diencephalon of Carnivora. III. Certain myelinated fiber connection of the diencephalon of the dog (Canis familiaris), cat (Felis domestica), and aevisa (Crossarchus obseurus). J. Comp. Neur., vol. 53, pp. 319-388.

1934 Certain myelinated fiber tracts of the brain stem of the cat. Anat. Rec., vol. 58, supplement, p. 84. 
Shanklin, W. M. 1933 The comparative neurology of the nucleus opticus tegmenti with special reference to Chameleon vulgaris. Acta Zool., vol. 14 , pp. 163-184.

Simpson, F. 1903 The book of the cat. Cassell \& Co., Ltd., London, Paris, New York \& Melbourne.

STERzI, G. 1914-1915 Anatomia del sistema nervoso centrale dell'uomo. 2 vols., Padova. (Quoted from Ariëns Kappers, Huber and Crosby, '36.)

Suzuki, N. 1936 The diencephalon and some other systems in Xantharpyia amplexicaudata. I. Proc. Kon. Akad. v. Wetensch. te Amsterdam, Bd. 39 , S. $766-773$.

TsaI, C. 1925 The optic tracts and centers of the opossum, Didelphis virginiana. J. Comp. Neur., vol. 39, pp. 173-216.

Wallenberg, A. 1904 Notiz zur Anatomie des Tractus peduncularis transversus beim Meersehweinehen. Anat. Anz., Bd. 24, S. 199. 